\title{
Kinesio Taping decreases healing area and modulates the tissue architecture on the
}

\section{cutaneous wound}

Kinesio Taping contribui na redução da área de cicatrização e modula a arquitetura do tecido reparacional cutâneo

Kinesio Taping contribuye a la reducción del área de cicatrización y modula la arquitectura del tejido de reparación de la piel

\begin{abstract}
The skin is an organ that promotes elasticity and also resistance against mechanical forces. After injury, its organization is altered by the repair process, compromising the physiological mechanical conditions of the skin. In this context, it has been demonstrated that Kinesio Taping (KT) accelerates the cicatricial process and prevents the development of skin adhesions, but other actions of this method in the cutaneous repair tissue remain indeterminate. Objective: To investigate the histological effects of KT in tissue repair of cutaneous wound. Methods: The procedure involved the preparation and suturing of an incisional wound of $5 \mathrm{~cm}$ in length on the epilated back of Wistar rats. After ten days, KT was applied with different stretch levels - 0, 20, 40, 60, 80 and 100\% - for six hours. The skin fragment corresponding to the scar was collected and analysed by histological procedures. Results: KT decreased repair tissue area, regardless of the degree of strain, while mast cells activity was not affected by the treatment. 80\% stretched KT increased the vascular density of repair tissue. Also, there was a predominance of type III collagen fibers over type I in all groups treated with KT and modulation in tissue architecture in GKT100.
\end{abstract}

Keywords: Wound healing; Tensile strength; Collagen.

\section{Resumo}

A pele é um órgão que promove elasticidade e também resistência às forças mecânicas. Após a lesão, sua organização é alterada pelo processo de reparo, comprometendo as condições mecânicas fisiológicas da pele. Nesse contexto, tem sido demonstrado que o Kinesio Taping (KT) acelera o processo cicatricial e previne o desenvolvimento de aderências cutâneas, mas outras ações desse método no tecido de reparo cutâneo permanecem indeterminadas. Objetivo: Investigar os efeitos histológicos do KT na reparação tecidual de feridas cutâneas. Métodos: O procedimento envolveu o preparo e sutura de uma incisão incisional de $5 \mathrm{~cm}$ de comprimento no dorso depilado de ratos Wistar. Após dez dias, o KT foi aplicado com diferentes níveis de alongamento - 0, 20, 40, 60, 80 e 100\% - por seis horas. O fragmento de pele correspondente à cicatriz foi coletado e analisado por meio de procedimentos histológicos. Resultados: o KT diminuiu a área do tecido de reparo, independente do grau de deformação, enquanto a atividade dos mastócitos não foi afetada pelo tratamento. O KT alongado em $80 \%$ aumentou a densidade vascular do tecido de reparo. Além disso, houve predomínio de fibras de colágeno tipo III sobre o tipo I em todos os grupos tratados com KT e modulação na arquitetura do tecido no GKT100.

Palavras-chave: Cicatrização; Resistência à tração; Colágeno. 


\section{Resumen}

La piel es un órgano que favorece la elasticidad y también la resistencia a las fuerzas mecánicas. Después de la lesión, su organización se ve alterada por el proceso de reparación, comprometiendo las condiciones fisiológicas mecánicas de la piel. En este contexto, se ha demostrado que Kinesio Taping (KT) acelera el proceso cicatricial y previene el desarrollo de adherencias cutáneas, pero otras acciones de este método en el tejido de reparación cutánea permanecen indeterminadas. Objetivo: investigar los efectos histológicos del KT en la reparación tisular de la herida cutánea. Métodos: El procedimiento implicó la preparación y sutura de una herida incisional de $5 \mathrm{~cm}$ de longitud en el lomo depilado de ratas Wistar. Después de diez días, se aplicó KT con diferentes niveles de estiramiento - 0, 20, 40, 60, 80 y 100\% - durante seis horas. El fragmento de piel correspondiente a la cicatriz se recogió y analizó mediante procedimientos histológicos. Resultados: KT disminuyó el área del tejido de reparación, independientemente del grado de tensión, mientras que la actividad de los mastocitos no se vio afectada por el tratamiento. El 80\% de KT estirado aumentó la densidad vascular del tejido de reparación. Además, hubo un predominio de las fibras de colágeno tipo III sobre el tipo I en todos los grupos tratados con KT y modulación en la arquitectura tisular en GKT100.
\end{abstract}

Palabras clave: Cicatrización de heridas; Resistencia a la tracción; Colágeno.

\title{
1. Introduction
}

Skin is an organ that is constantly adapting to dynamic physical stimuli present during all periods of life, which is a requirement for growth, healing and survival.(Agha, Ogawa, Pietramaggiori \& Orgill, 2011; Wong, Akaishi, Longaker \& Gurtner, 2011) The skin has two main layers, the epidermis and the dermis. The first one is in direct contact with the external environment and the second is a resistant layer of dense irregular connective tissue, with fibroblasts and other connective cells, collagen and elastic fibers arranged in different directions.(Young, Lowe \& Stevens, 2006) These fibers are immersed in the Amorphous Fundamental Substance called ground substance, a hydrated material composed of glycosaminoglycans, proteoglycans and glycoproteins, giving the tissue the ability to withstand applied forces. (Wong et al., 2011) Collagen fibers and ground substance form the Extracellular Matrix (ECM) of connective tissue and provide elasticity and resistance against intrinsic and extrinsic forces.(Agha et al., 2011; Ogawa, 2011)

It is noteworthy that molecules act collectively within this integrated and hierarchical system controlling early tissue development, as well as wound healing.(Kubow, Vukmirovic, Zhe, Klotzsch, Smith \& Gourdon, 2015) However, it has been demonstrated that such hierarchy in the organization of cells and matrix of a system can be mechanically regulated when its architecture is disturbed.(Wong et al., 2011; Ogawa, 2011; Verhaegen, Schouten, Tigchelaar-Gutter, van Marle, van Noorden \& Middelkoop, 2012) It is known that after injury, the organization and mechanical physiological conditions of the skin are altered by the repair process, which involves the inflammatory, proliferative, remodeling and reepithelization phases.(Ogawa, 2011; Isaac, Ladeira, Rego, Aldunate \& Ferreira, 2010) These phases comprise simultaneous processes that consist of a perfect and coordinated cascade of cellular, molecular and biochemical events that interact to produce tissue reconstitution and they are all influenced by mechanical forces.(Agha et al., 2011; Benavides, 2008; Campos, Borges-Branco \& Growth, 2007)

Evidences show that cell-matrix interactions are mechano regulated responding in different ways to several types of mechanical forces, such as compression, stretch, shear and gravity, which can be applied by means of silicone sheets, bandages and garments.(Agha et al., 2011; Costa, Peyrol, Pôrto, Comparin, Foyatier \& Desmoulière, 1999; Wong et al., 2011; Ogawa, 2011) Among these different ways of applying extrinsic mechanical force, Kinesio Taping ${ }^{\circledR}$ (KT) has been used in several studies and in clinical practice by many physiotherapists worldwide as a complementary resource in the rehabilitation process.(Parreira, Costa, Hespanhol-Jr, Lopes \& Costa, 2014; Yasukawa, Patel \& Sisung, 2006) Created in 1973 by Dr. Kenzo Kase, the method consists of the special application of elastic bandages directly on the skin, since these bandages are developed with elastic properties similar to those of the skin and manufactured with $100 \%$ cotton and elastic fibers, which ensures elasticity in the longitudinal direction.(Donec \& Kriščiūnas, 2014; Lemos, Pereira, Protássio, Lucas \& Matheus, 2015) Once applied, they can be used for long periods, maintaining their therapeutic benefits, such as normalizing muscle function, 
reducing pain and inflammation, improving joint malalignment and joint proprioception and improving lymphatic and blood flow, which are reported to be result of skin deformation.(Kase, Willis \& Kase, 2003; Cimino, Beaudette \& Brown, 2018)

Recent evidences have also shown the potential benefit of KT in accelerating healing process and preventing the development of adhesions and significantly affecting skin surface stretch.(Cimino et al., 2018; Szczegielniak, Łuniewski \& Bogacz, 2007) Thus, considering that healing tissue is responsive and able to adapt to extrinsic forces, the elastic properties of the KT bandage and that all of its benefits may be dependent on the stretch of the skin, the purpose of this study was to evaluate the effects of the KT method in the process of tissue repair, vascularization and collagen fiber in scar tissue of incisional wounds.

\section{Methodology}

\section{Study Design}

This study is a qualitative and quantitative study, in which quality is obtained from the measurement of quantity and quality can be classified from quantitative data. This study is an in-vivo animal preclinical research project. (Pereira, Shitsuka, Parreira, \& Shitsuka, 2018).

\section{Animals}

Adult male Wistar rats ( 35 animals, 60 days old, $180 \mathrm{~g}$ body weight) were kept at the animal house under controlled temperature $\left(23^{\circ} \mathrm{C}-25^{\circ} \mathrm{C}\right)$, light and dark cycle of 12 hours and given standard rodent chow (Nuvital ${ }^{\circledR}$ - Nuvilab, Brazil) and water ad libitum. The experimental protocol was conducted in accordance with ethical principles adopted by the National Council for the Control of Animal Experimentation (CONCEA) and approved by the Ethics Committee in Animal Experimentation (CEUA) of UEM (Permit number: 8337190216).

\section{Experimental Design}

Animals were divided into seven groups $(\mathrm{n}=5)$ according to the KT treatment, namely:

- Group C - control group without KT application;

- Group KT0 - group treated with KT without strain;

- Group KT20 - group treated with KT with $20 \%$ strain;

- Group KT40 - group treated with KT with $40 \%$ strain;

- Group KT60 - group treated with KT with $60 \%$ strain;

- Group KT80 - group treated with KT with $80 \%$ strain and

- Group KT100 - group treated with KT with 100\% strain.

\section{Surgical Technic}

In order to make the wounds, the animals were anesthetized (thiopental $40 \mathrm{mg} . \mathrm{kg}$ body weight-1, intraperitoneal) and their backs were epilated. After asepsis, a longitudinal incision of $5 \mathrm{~cm}$ in length was made with the aid of a scalpel, and then it was sutured with single continuous stitches using 5-0 Nylon non-absorbable thread, PolySuture ${ }^{\circledR}$. The single continuous suture technique was chosen because it ensures that the strength is evenly distributed throughout the incision length and not concentrated at specific points of the suture, as in the case of discontinuous sutures. In addition, compared to other types of continuous sutures, this technique confers less strain capable of influencing the collagen response. (Loureiro, Fagundes \& Taha, 2003) 


\section{Kinesio Taping Treatment}

Seven days after making the incision, the stitches were removed, as suggested by Gal et al. (2006) and, on the $10^{\text {th }}$ day, the animals were anesthetized for six hours (thiopental $40 \mathrm{mg} . \mathrm{kg}$ body weight ${ }^{-1}$, intraperitoneal) for epilation of the wound region and bonding Kinesio Tex Gold ${ }^{\mathrm{TM}}$ bandages. (Parreira et al., 2014) The bandages were applied using the Fan technique in two sequences in opposite directions with an oblique orientation to the scar (Figure 1). Strains were produced manually by varying the length of the KT bandage in its longitudinal direction, always by the same researcher. The application of Fan KT, besides generating strain in several directions, like the orientation of the own collagen present in the epithelial tissue, stimulates the creation of channels - areas of compression and decompression - that reduce the pressure in the congested areas. The six-hour intervention period was adopted based on Kafa et al. (2015) and considering the maximum time of anesthetic effect.(19)

Figure 1. The KT bandage applied to the back of the experimental animals.

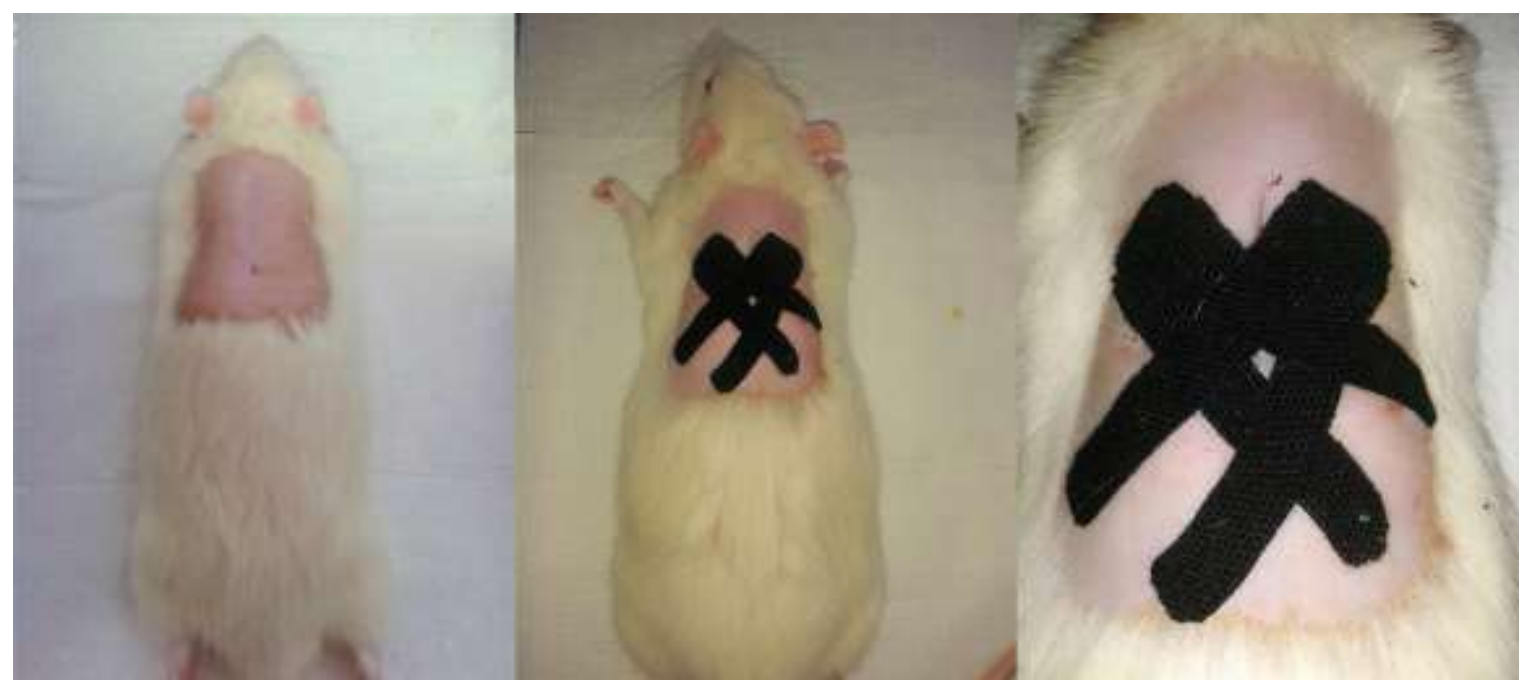

Source: Authors.

In Figure 1, we can see the placement of the bandages at the moment of application on the animal's back, after the healing period.

\section{Histological Procedures, Healing Area Measurement And Vascular Density Evaluation}

After the 6 hours treatment period, the KT bandages were removed and the skin fragment corresponding to the scar was collected and fixed in Bouin solution (picric acid: formic acid: acetic acid 75: 25: $5 \mathrm{v} / \mathrm{v}$ ) for 24 hours, followed by routine histological procedure. The material was submitted to $6 \mu \mathrm{m}$ thick semi-serial sections stained by the Hematoxylin and Eosin (HE), Mallory-Azan, Dominici and Picrosirius Red techniques.

Slides stained by the HE technique were evaluated by light microscopy (Nikon YS29) coupled to an image capture system as for the healing area $\left(\mu \mathrm{m}^{2}\right)$ and vascular density. The scar area in the histological sections' images stained with the HE technique, analyzed with a 10x objective, was delimited and quantified by the software Image Pro-Plus ${ }^{\circledR}$ version 4.5 . The area corresponding to the epithelium was disregarded in the quantification of the scar area.

Also, slides stained with the HE technique, analyzed with a 20x objective, were used for manual counting of the total number of blood vessels. Vascular density was obtained from the ratio of the total number of blood vessels counted to the scar area. The scar area and density analyses were performed in five replicates for each histological slide. 


\section{Mast Cell Counting}

The mast cell count, with the slides stained by the Dominici technique, was performed in microscopic fields using a reticulum of 100 grids into the eyepiece of the light microscope (Nikon YS29) in a 20X objective. The areas analyzed were determined following a straight line by the extension of the scar area. Then, the adjacent regions of both sides of the injury zone were analyzed, as well as two more fields on each side, characterizing the peripheral area.

\section{Type I And lii Collagen Fibers Quantification And Deposition}

Slides stained with the Picrosirius Red technique were evaluated under a polarized light microscope (Nikon YS29; Attachment Nszh-KPO Polarizer) - for quantification of the area $\left(\mu \mathrm{m}^{2}\right)$ occupied by type I and III collagen fibers and using the software Image Pro-Plus ${ }^{\circledast}$ 4.5. The analysis of the Picrosirius Red staining was by birefringence of the collagen fibers type I (red/yellow) and III (green) of the papillary layer of the skin. All analyses were performed in triplicate for each slide and in each histological section was standardized for counting the central field and two lateral fields of the scar of the papillary layer of the dermis.(Cuttle, Nataatmadja, Fraser, Kempf, Kimble \& Hayes, 2005) A 20X objective was used for the analyses.

Slides stained by the Mallory-Azan technique were evaluated by light microscopy (Nikon YS29) coupled to an image capture system as for the collagen deposition. Analyses were performed with a 10x objective.

\section{Statistical Analysis}

Data collected were tested by the Kolmogorov-Smirnov (K-S) test to check normality. In order to compare the groups - regarding the scar area and vascular density - we used one-way analysis of variance (ANOVA) with Tukey post-hoc test, and a two-way analysis of variance was applied to compare the area occupied by collagen fibers and mast cells with Bonferroni post-test, in both cases, with the level of significance set at $95 \%$ ( $\mathrm{p}<0.05)$ with the aid of software GraphPad Prism 5.0.

\section{Results}

Incisional wounds were made in the back of Wistar rats and, after ten days, the scar area was treated for six hours with KT bandage in order to evaluate its effects on the repair tissue. Our results reveal that extrinsic mechanical stretch applied with KT for the six-hour period in animal scar tissue generally reduced the tissue repair area, as presented in Figure 2. The histological analysis demonstrates, in a qualitative way, reduction of scar area in all tissues subjected to treatment with KT in comparison to GC. Complementing these observations, significant results for such reduction were obtained in the comparison of all KT-treated groups relative to GC. These findings show that the mechanical stretch applied by the KT method, regardless of the degree of strain, was able to improve the tissue repair response, observed by the reduction in scar area. 
Figure 2. Histological representation of the control group and test group (A) and Graph corresponding to the scar area for each experimental group.
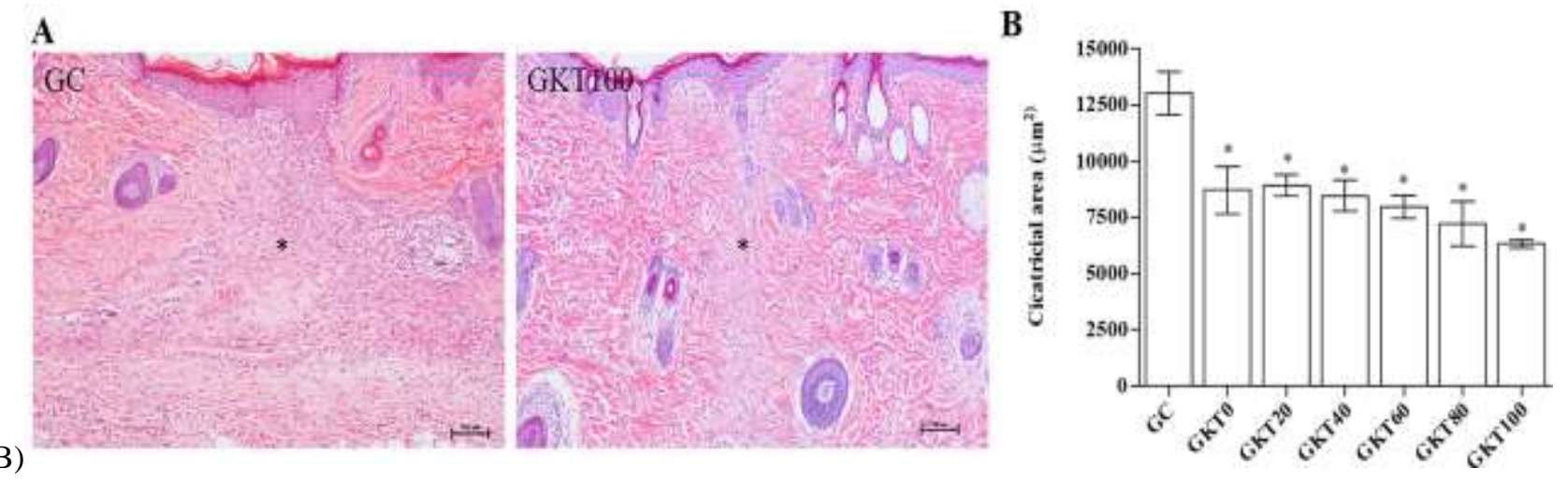

Source: Authors.

In Figure 2, we can see the visible difference between the control group (CG) and the group with $100 \%$ bandage tensioning (KT100), reducing the healing area $(*)$ (A). In (B) we can observe the different values attributed to the healing area after treatment for each group.

The quantification of mast cells in the repair tissue, performed from cell counts in slides stained by the Dominici technique, revealed a greater number of mast cells in the peripheral area of the injury zone. The result was also significant in comparison to the scar region itself and the adjacent region. The comparison of these last two regions revealed that, in the KT0 group, there was a greater number of mast cells in the immediately adjacent region than in the cicatricial tissue. Still, such number of cells in the peripheral tissue of such group was also proved to be higher than in the other groups. With regard to the scar region itself, the mean number of cells in all groups was statistically equal. Like showed in Table 1.

Table 1. Mast cells quantification in scar tissue ten days after incisional wound.

\begin{tabular}{cccccccc}
\hline Area & CG & GKT0 & GKT20 & GKT40 & GKT60 & GKT80 & GKT100 \\
\hline Injury & $6,7 \pm 1,67$ & $5,83 \pm$ & $8,00 \pm 0,84$ & $7,08 \pm 1,41$ & $7,27 \pm 1,33$ & $3,97 \pm 0,62$ & $8,57 \pm 0,49$ \\
& & $0,53^{*}$ & & & & & \\
Adjacent & 20,08 & & & & & & \\
& $\pm 2,24 *$ & $34,33 \pm 3,90$ & $\pm 1,43 *$ & $\pm 2,34 *$ & $\pm 1,42 *$ & $\pm 1,62 *$ & $\pm 2,82 *$ \\
Peripheral & 125,70 & 114,70 & 130,50 & 117,50 & 119,10 & 114,40 & 124,10 \\
& $\pm 6,78 \#$ & $\pm 13,90 \#$ & $\pm 9,64 \#$ & $\pm 9,88 \#$ & $\pm 8,25 \#$ & $\pm 6,21 \#$ & $\pm 8,03 \#$ \\
\hline
\end{tabular}

* p $<0,05$ vs GKT0 of the Adjacent area; \# $<<0.05$ vs respective group of Injury area and Adjacent area. Data reported as mean \pm SD, $\mathrm{n}=$ 5/group. Two-way ANOVA/Bonferroni.

Source: Authors.

For the blood vessel count, a statistically significant difference $(\mathrm{p}<0.05)$ was observed for the KT80 group compared to the control group. (Figure 3) The other groups also showed an increase in the number of blood vessels, however, nothing statistically relevant. 
Figure 3. Number of blood vessels per scar area in the repair tissue.

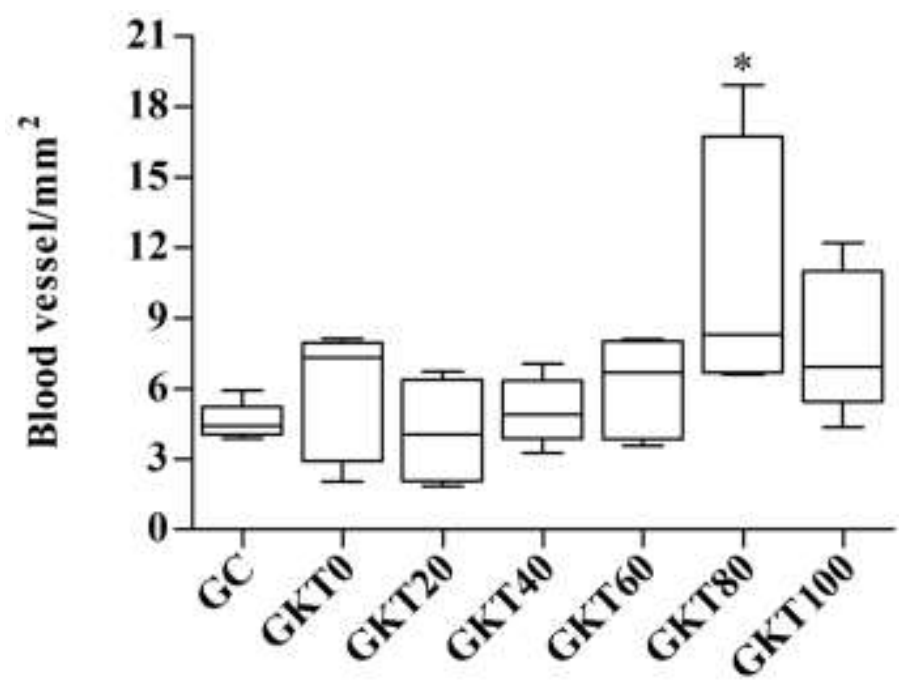

Source: Authors.

Figure 3 shows the vascular density (number of blood vessels per scar area) in the repair tissue. The results indicated a significant increase of blood vessels in the repair tissues of KT-treated animals with $80 \%$ strain.

The quantification of collagen fibers present in the scar tissue of Wistar rats, presented in Figure 4, revealed balance in the presence of type I and type III collagen fibers in the GC. Such balance was altered by mechanical stretch treatment, since there was a predominance of type III collagen fibers in relation to type I in groups KT0, KT40, KT80 and KT100. Furthermore, analysis between groups revealed a higher synthesis of type III collagen fibers in tissues treated with $40 \%$ strain compared to GC and the other groups treated, whereas, in relation to GC, type I collagen production decreased, similarly, in all groups treated with $\mathrm{KT}$.

Figure 4. Collagen fibers quantification present in the dorsal scar tissue of Wistar rats.

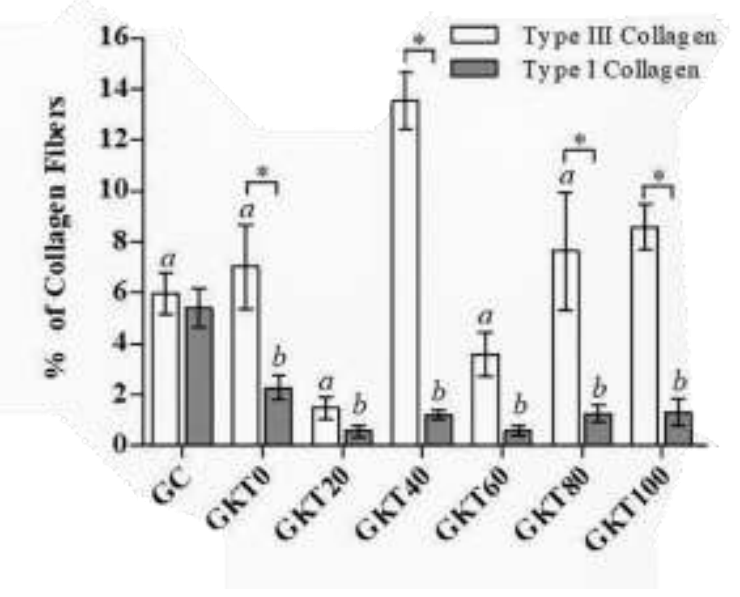

Source: Authors.

In Figure 4 it is possible to check the corresponding graph of the values of collagen I and collagen II arranged in the healing area of the animals. 
Regarding the arrangement and organization of these fibers, in the qualitative analysis of slides stained with Mallory Azan (Figure 5), it was observed that, in general, the coloration was lighter in the scar area (*) compared to the adjacent region, which is due to the smaller number of collagen fibers. Small areas of edema in the scar region of all groups were also verified. In addition, the predominance of type III collagen described previously provided the scar region with loose tissue characteristics. On the other hand, in the GKT100, there was the formation of bundles of collagen fibers and that the arrangement and organization of the fibers was more similar to the adjacent tissue, which was not observed in the other groups.

Figure 5. Fibers arrangement and organization in the scar area.

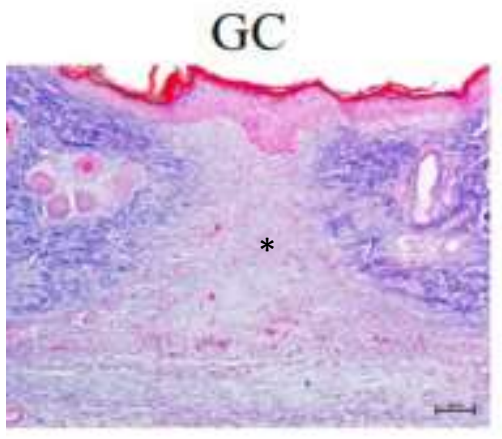

GKT60

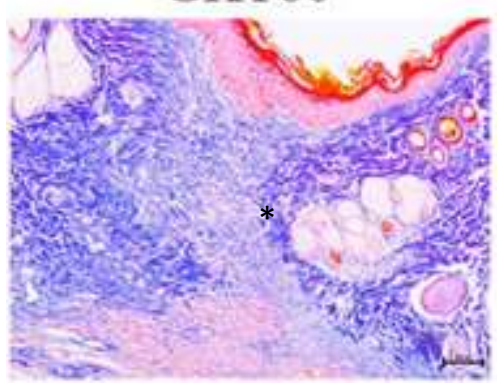

GKT20

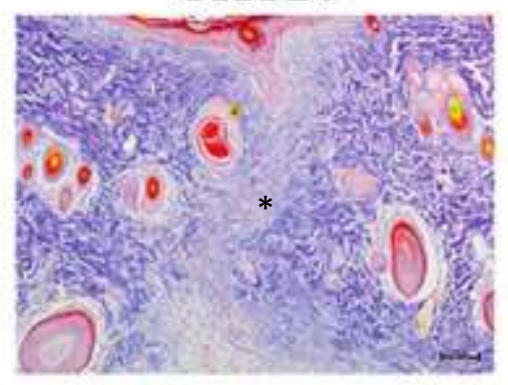

GKT80

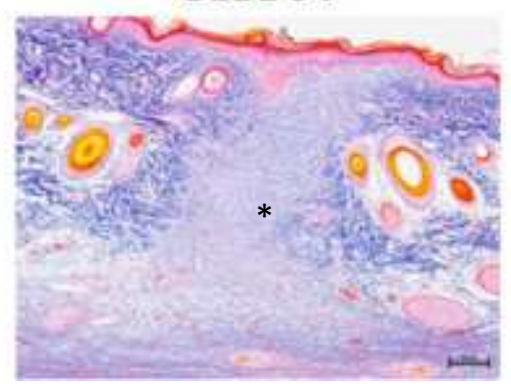

GKT40

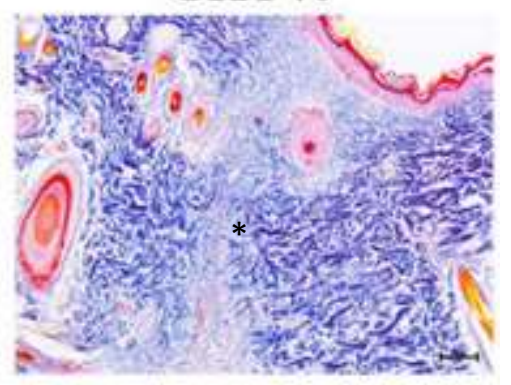

GKT100

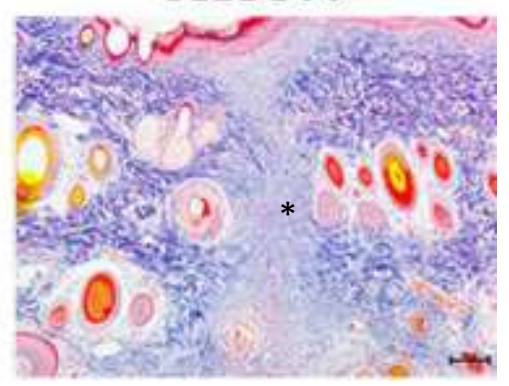

Source: Authors.

In Figure 5, it is possible to observe the disposition of the fibers and the final scar area after Kinesio taping therapy in its different tensioning forces, calling attention to the reduction of the scar area of all groups that used the bandage.

\section{Discussion}

Kinesio Taping ${ }^{\circledR}(\mathrm{KT})$ is a commonly used intervention in the treatment for several clinical conditions and, regardless its popularity, there is little evidence about its efficacy and effectiveness and its actions on cutaneous healing tissue remain undetermined.(Parreira et al., 2014) Therefore, no important descriptive patterns were found in the literature to compare all of the findings of this study.

It is indicated that KT bandage provides constant traction force to the skin, providing an increase in the function of the epidermis and dermis; however, evidence for such a theory has yet to be found.(Kase et al., 2003) Our study showed for the first time, to our knowledge, that KT method decreased the scar tissue area in repair process. These results may support the hypothesis that KT increases skin function as they reveal that the treatment with KT alone was able to improve tissue healing response, since there was a significant reduction of the scar area in the GKT0 in comparison to control and, also, statistically similar results for all groups treated with the bandage.

The role of mast cells at the onset of tissue repair and the finding that scarring is dependent on their activity has 
already been demonstrated in the literature and, therefore, counting of mast cells was performed in this research.(Weller, Foitzik, Paus, Syska \& Maurer, 2006) Studies have already shown that mast cells are more numerous and their activation more evident in the tissue adjacent to the wound, and not in the scar area itself, similar to our results.(Weller et al., 2006; Barreto, Bastos \& Pires, 2013) It is suggested that the reduced number of mast cells in this area may be related to the mast cell mediated action on residual peripheral vessels and nerves, even in the later stages of tissue repair, and not directly on the injury.(Barreto et al., 2013; Balbino, Pereira \& Curi, 2005) Also, considering that our results did not vary between the analyzed groups, we assume that the activation of the mast cells and their role in the tissue repair process are not modulated by mechanical stretch.

Literature also states that the effects of mechanical strain do extend to vascular tissue, influencing the neovascularization process.(Erba, Miele, Adini, Ackermann, Lamarche \& Orgill, 2011; Pietramaggiori, Liu, Scherer, Kaipainen, Prsa \& Mayer, 2007) As showed in Figure 3, there was a significant increase in vascular density of tissues treated with $80 \%$ of KT strain. Although the explanation for such an outcome is not yet known, clinical evidence from Martins (2014) also suggests that the vascular effects seen in post-operative patients are better with KT submaximal stretches than minimum or maximum ones.(Martins, 2014) Parallelly to this subject, it is indicated that, after application, KT pulls the skin changing its contour and then the bandage retracts back to its original length, creating convulsions on the underlying skin. Such convulsions are known to increase the interstitial space between the epidermis and the underlying connective tissue and thus the circulation of blood and lymph fluids is facilitated, which is responsible for the effect of KT on reducing edema.(Kase et al, 2003) In this study, it was histologically shown small areas of edema in the scar region of all groups ten days after injury (Figure 5), while edematous area is found to be decreased in the literature. (Kafa, Citaker, Omeroglu, Peker, Coskun \& Diker, 2015) Such divergence could be explained by time-dependence of the healing process, in which infiltrate plasma is early substituted by components of the new ECM. (Balbino et al., 2005)

It is known that during the remodeling phase, the granulation tissue is enriched with more collagen fibers, especially type I, giving it the appearance of a fibrotic mass, as observed in our control group (Figure 5), and that the maturation of this type I collagen occurs simultaneously with the degradation of type III fibers, thus corroborating with the balance in the number of collagen fibers found in the same group showed in Figure 4. (Balbino et al., 2005; Toriseva \& Kahari, 2009)

However, the results related to KT groups presented in Figure 4 showed a predominance of type III collagen fibers over type I. It is assumed that the increase of force or strain can modulate the balance between synthesis and degradation of ECM components, in which mechano regulation among structural ECM proteins initially directs the hierarchical assembly of ECM by regulating collagen I localization and, later, mature collagen fibers stabilize elongation against cell traction forces. (Rolin, Binda, Tissot, Viennet, Saas \& Muret, 2014) Furthermore, this predominance of type III collagen fibers by mechanical strain with KT is characteristic of the granulation phase, in which, as observed in herein, the scar tissue is edematous and full of voids, which also resulted in a decrease in the total number of collagen fibers per area of scar tissue observed in GKT20. (Balbino et al., 2005) Moreover, fiber bundle formation and scar tissue organization observed in GKT100 evidenced the promising role of mechanical stretch with KT in modulating the architecture of cutaneous repair tissue.

\section{Conclusion}

To our knowledge, this is the first study using KT in scar repair analysis, the results of which were obtained after six hours of bandaging, a limited time period. Our results revealed a significant reduction in the scar area in all tissues subjected to KT strain, a significant increase in the vascular density of scar tissue subjected to $80 \%$ strain, in addition to the predominance of type III collagen fibers and reduction of type I collagen fibers. These findings led us to conclude that KT bandaging was able to cause changes in scar tissue and may influence the healing process of the skin, but further molecular studies are still 
required to find out how the mechanisms occur. Nevertheless, these results suggest potential benefits of KT in modulating the architecture and function of cutaneous repair tissue.

\section{Disclosure of interest}

The authors declare that the research was conducted in the absence of any commercial or financial relationships that could be construed as a potential conflict of interest.

\section{References}

Agha, R., Ogawa, R., Pietramaggiori, G., \& Orgill, D. P. (2011). A review of the role of mechanical forces in cutaneous wound healing. J Surg Res.;171: 7008 .

Balbino, C. A., Pereira, L. M., \& Curi, R. (2005). Mecanismos envolvidos na cicatrização: uma revisão. Rev. Bras. Cienc. Farm.;41: $27-51$.

Barreto, A. L. S., Bastos, T. S., \& Pires, J. Á. (2013). Análise quantitativa de mastócitos na cicatrização de feridas tratadas com membranas de colágeno contendo própolis vermelha. Interfaces Científias - Saúde e Ambiente.;1: 79-90.

Benavides, J. Reparación de heridas cutáneas. Rev. Asoc. Col. Dermatol, 2008;16: 29-35.

Campos, A. C. L., Borges-branco, A., \& Growth, A. K. (2007). Cicatrização de feridas. ABCD, Arq Bras Cir Dig. $20: 51-8$.

Cimino, S. R., Beaudette, S. M., \& Brown, S. H. M. (2018). Kinesio taping influences the mechanical behaviour of the skin of the low back: A possible pathway for functionally relevant effects. J Biomech. 23;67: 150-6.

Costa, A. M., Peyrol, S., Pôrto, L. C., Comparin, J. P., Foyatier, J. L., \& Desmoulière, A. Mechanical forces induce scar remodeling. Study in non-pressuretreated versus pressure-treated hypertrophic scars. Am J Pathol. 1999; 155: 1671-9.

Cuttle, L., Nataatmadja, M., Fraser, J. F., Kempf, M., Kimble, R. M., \& Hayes, M. T. Collagen in the scarless fetal skin wound: detection with picrosiriuspolarization. Wound Repair Regen. 2005; 13: 198-204.

Donec, V., \& Kriščiūnas, A. The effectiveness of Kinesio Taping® after total knee replacement in early postoperative rehabilitation period. A randomized controlled trial. Eur J Phys Rehabil Med. 2014; 50: 363-71.

Erba, P., Miele, L. F., Adini, A., Ackermann, M., Lamarche, J. M., Orgill, B. D, et al. A morphometric study of mechanotransductively induced dermal neovascularization. Plast Reconstr Surg. 2011; 128: 288-99.

Isaac, C., Ladeira, P. R. S., Rego, F. M. P., Aldunate, J. C. B., \& Ferreira, M. C. Processo de cura das feridas: cicatrização fisiológica. Rev. Med. 2010; 89: $125-31$.

Kafa, N., Citaker, S., Omeroglu, S., Peker, T., Coskun, N., \& Diker, S. Effects of kinesiologic taping on epidermal-dermal distance, pain, edema and inflammation after experimentally induced soft tissue trauma. Physiother Theory Pract. 2015; 31: 556-61.

Kase, K., Willis, J., \& Kase, T. Clinical therapeutic applications of the kinesiotaping method. Kinesio Taping Association. 2003.

Kubow, K. E., Vukmirovic, R., Zhe, L., Klotzsch, E., Smith, M. L., Gourdon, D., et al. Mechanical forces regulate the interactions of fibronectin and collagen I in extracellular matrix. Nat Commun. 2015; 14: 802-6.

Lemos, T. V., Pereira, K. C., Protássio, C. C., Lucas, L. B., \& Matheus, J. P. The effect of Kinesio Taping on handgrip strength. J Phys Ther Sci. 2015;27: $567-70$.

Loureiro, V. M., Fagundes, D. J., \& Taha, M. O. Síntese da parede abdominal: avaliação de dois tipos de sutura contínua em ratos. Acta Cir. Bras. 2003;18: 14.

Martins, M. Kinesio Taping ${ }^{\circledR}$ aplicado à cirurgia plástica. In: Lange A. Fisioterapia dermato-funcional aplicada à cirurgia plástica. Curitiba: Victória Gráfica \& Editora. 2014.

Ogawa, R. Mechanobiology of scarring. Wound Repair Regen. 2011; 19: 2-9.

Parreira, P. C., Costa, L. C., Hespanhol-Jr, L. C., Lopes, A. D., \& Costa, L. O. Current evidence does not support the use of Kinesio Taping in clinical practice: a systematic review. J Physiother. 2014; 60: 31-9.

Pereira, A. S., Shitsuka, D. M., Parreira, F. J., \& Shitsuka, R. (2018). Methodology of cientific research. UAB / NTE / UFSM. https://repositorio.ufsm.br/bitstream/handle/1/15824/Lic_Computacao_Metodologia-Pesquisa-Cientifica.pdf?sequence=1\&isAllowed=y

Pietramaggiori, G., Liu, P., Scherer, S. S., Kaipainen, A., Prsa, M. J., Mayer, H., et al. Tensile forces stimulate vascular remodeling and epidermal cell proliferation in living skin. Ann Surg. 2007. 246: 896-902.

Rolin, G. L., Binda, D., Tissot, M., Viennet, C., Saas, P., \& Muret, P., et al. In vitro study of the impact of mechanical tension on the dermal fibroblast phenotype in the context of skin wound healing. J Biomech. 2014;47: 3555-61. 
Research, Society and Development, v. 10, n. 1, e41110111888, 2021 (CC BY 4.0) | ISSN 2525-3409 | DOI: http://dx.doi.org/10.33448/rsd-v10i1.11888

Szczegielniak, J., Łuniewski, J., Bogacz, K., et al. The possibilities of using ki-nesio taping in patients after cardiac surgery. Fizjoterapia Polska 2007; 4: 45671

Toriseva, M., Kahari, V. M. Proteinases in cutaneous wound healing. Cell Mol Life Sci. 2009; 66: $203-24$.

Verhaegen, P. D., Schouten, H. J., Tigchelaar-Gutter, W., van Marle, J., van Noorden, C. J., Middelkoop, E., et al. Adaptation of the dermal collagen structure of human skin and scar tissue in response to stretch: an experimental study. Wound Repair Regen. 2012; 20: 658-66.

Weller, K., Foitzik, K., Paus, R., Syska, W., \& Maurer, M. Mast cells are required for normal healing of skin wounds in mice. FASEB J. 2006 ; 20 : 2366-8.

Wong, V. W., Akaishi, S., Longaker, M. T., \& Gurtner, G. C. Pushing back: wound mechanotransduction in repair and regeneration. J Invest Dermatol. 2011; 131: $2186-96$.

Yasukawa, A., Patel, P., \& Sisung, C. Pilot study: investigating the effects of Kinesio Taping in an acute pediatric rehabilitation setting. Am J Occup Ther. 2006; 60: 104-10.

Young, B., Lowe, J. S., Stevens, A., \& Heath, J. W. Wheater: Histologia funcional: texto e atlas em cores. (4th. ed.): Guanabara Koogan; 2006. 